\title{
PERBANDINGAN EKONOMI ADAT MINANGKABAU DENGAN EKONOMI ISLAM
}

\section{THE COMPARISON OF THE MINANGKABAU TRADITIONAL ECONOMY WITH THE ISLAMIC ECONOMY}

\author{
Yunimar, Zakaria, dan Annesy \\ Sekolah Tinggi Ekonomi Syariah MANNA WA SALWA Tanah Datar \\ Jl. Raya Padang Panjang - Bukittinggi KM.3 Pincuran Tinggi Sepuluh Koto Tanah Datar \\ yunimar1986@gmail.com, zakaria1310@gmail.com, mrstaufik1@gmail.com
}

Naskah diterima 28 Mei 2019, di-review 27 Juni 2019, disetujui 29 Juni 2019

\begin{abstract}
Years Ago, the Minangkabau tribe Community in West Sumatera as the the largest matrilineal in the world, has a communal economic system based on the Minangkabau tradition with a proto-democratic system. This paper aims to analyze the comparison of traditional economies with Islamic economics. The research method is descriptive qualitative by conducting surveys and focused group discussion (FGD). The results show Minang people who obey the Islamic rules and Minang custom do not carry out the Islamic economy system. It is because the influence of social and cultural side such as the capitalist economy system. As a result, there will be less togetherness between people based on the philosophy of "Adat Basandi Sa'arak, Syarak Basandi Kitabullah".
\end{abstract}

Keywords: Minangkabau Tribe, Islamic Economy, Comparison

\begin{abstract}
Abstrak: Sejak dahulu Masyarakat adat Minangkabau selaku penganut matrilinial terbesar di dunia, telah memiliki sistem perekonomian komunal berdasarkan Adat Minangkabau dengan sistem protodemokrasi sejak masa pra sejarah. sehingga terkenal sebagai Saudagar Minang yang menguasai perekonomian. Metode ini penelitian adalah deskriptif kualitatif dengan melakukan survey dan focussed group discusion (FGD) guna menganalisa perbandingan ekonomi adat dengan Ekonomi Islam. Hasil Penelitian adalah terdapat persamaan nilai-nilai ekonomi Islam dengan nilai-nilai ekonomi adat Adat Minangkabau yaitu nilai-nilai kebersamaan dalam sistim ekonomi. Hasil penelitian ini juga menemukan faktor-faktor yang menggeser dan membuat jarak antara Ekonomi Adat Minangkabau dengan Ekonomi Islam. Dari segi faktor pelaku bisnis di Nagari maupun di rantau, orang Minang yang taat akan ajaran Islam dan loyal dalam melaksanakan Adat tapi belum bisa berperilaku Ekonomi Adat sesuai ajaran Islam. Pengaruh sosial politik dan budaya asing seperti sistem Ekonomi Kapitalis yang sangat mempengaruhi dan merubah pemikiran serta perilaku ekonomi orang Minang, sehingga pelaku ekonomi adat tidak lagi berprinsip teguh pendirian dan hilangnya rasa kebersamaan sesuai ajaran adat Minangkabau yang berlandaskan Filosofi "Adat Basandi Sa'arak, Syarak Basandi Kitabullah"
\end{abstract}

Kata Kunci: Perbandingan Ekonomi Adat Minangkabau Dengan Ekonomi Islam

\section{PENDAHULUAN}

Adat Minangkabau telah mengatur setiap pola kehidupan bermasyarakat, terutama dalam bidang ekonomi. Dalam masalah perekonomian telah diatur dalam sistim kebersamaan, baik adat, sako, pusako, dan ulayat (Amir, 2003: 95) merupakan milik bersama, serta di usahakan secara bergotong royong, mengelola sawah dan ladang secara bersama atau bergiliran demi kepentingan bersama, satu rumah gadang dihuni bersama-sama. Semua pengajaran adat Minang selalu mengutamakan kebersamaan yang menjadi darah daging bagi masyarakat adat Minang. 
Orang Minang sebagai pelaku usaha (bisnis) pada dasarnya memiliki rasa kebersamaan yang terkenal sebagai saudagar Minang. Orang Minang baik yang berdomisili di nagari atau kampung halaman atau dimanapun berada, senantiasa memiliki prinsip mengutamakan keuntungan bersama berdasarkan musyawarah dan mufakat. Dalam mengembangkan dan mensejahterakan perekonomian orang minang bukan hanya mengutamakan keuntungan dan kekayaan pribadi serta kelompok tertentu, dengan melakukan monopoli dan perbuatan ekonomi yang merugikan orang lain.

Pelaku pelaku ekonomi selama ini tanpa disadari telah bergeser dari nilai nilai ekonomi adat yang semestinya berbasis ekonomi Islam, sesuai filosofi "Adat Basandi Syarak, Syarak Basandi Kitabullah". Sedangkan ekonomi adat Minangkabau sejak dahulunya memakai prinsip ekonomi "lamak di awak, katuju di urang" yakni ekonomi saling menguntungkan (Tgk Irwansyah Datuk Katumangguangan, Pembekalan Adat Dinas Kebudayaan Profinsi Sumatera Barat2018).

Masyarakat adat Minang menganut konsep adat berazaskan Islam, artinya adat Minang merupakan sistem adat yang diperkokoh oleh hukum syariat Islam yang berdasarkan Kitabullah (Al Quran) dan telah banyak melahirkan pelaku ekonomi bertipologi pengusaha tangguh, dengan modal kearifan lokal genius ekonomi adat yang melekat. Namun pada kenyataannya masyarakat adat saat ini banyak tidak memahami tentang ekonomi adat dan ekonomi Islam, sehingga pelaku ekonomi adat yang mulai melupakan ekonomi Islam disebabkan kalah bersaing oleh pelaku ekonomi kapitalis yang individualis, hanya untuk memperkaya diri sendiri. Melihat perkembangan perekonomian dewasa ini sering terjadi tumpang tindih dan salah pahamnya penerapan antara ekonomi adat dan ekonomi Islam, disebabkan ketidaktauannya dan minimnya pendidikan ilmu ekonomi adat dan ekonomi Islam ditengah masyarakat, sehingga tidak optimal dalam melaksanakan sistem ekonomi adat berbasis ekonomi Islam (Nurdin, 1995: 53).

\section{METODE PENELITIAN}

Metode penelitian ini adalah deskriptif kualitatif dengan melakukan focussed group discusion (FGD) dan melakukan studi lapangan untuk memperoleh data primer dari narasumber yang layak terpecaya, guna menyusun data komunitas pelaku ekonomi adat di pasar tradisional Batusangkar dan sekitarnya dalam kabupaten Tanah Datar- Sumatera Barat.

Pengumpulan data primer dari berbagai sisi pengamatan untuk menggali kebiasaan pelaku ekonomi adat dalam melaksanakan prinsip ekonomi adat dan perbandingan dengan Pelaku ekonomi Islam, serta menggunakan data sekunder sebagai sumber data tambahan dengan alat analisis deskriptif dan verifikatif terhadap keseluruhan data yang di peroleh.

\section{PEMBAHASAN DAN HASIL}

\section{Pengertian Adat Minang}

Adat Minang adalah aturan perilaku hidup mulia, atau dalam bahasa arabnya adalah Ahlakul Karimah. Sedangkan Adat menurut masyarakat 
diluar etnis Minang adalah peraturan kebiasaan hidup sehari-hari. Bagi masyarakat Adat Minang bahwa tiap tarikan nafas serta setiap tingkah laku perbuatan senantiasa mengikuti aturan hidup mulia berazaskan Islam.

Menurut Tengku Irwansyah Angku Datuk Katumangguangan menyatakan "Apabila Masyarakat Adat Minangkabau tidak menjadikan adat sebagai "aie mandi, pakaian iduik" serta adat basandi syarak, syarak basandi kitabullah tidak dilaksanakan maka namanya "indak baradat". Jadi Adat Minang adalah aturan hidup mulia berazaskan Islam, berkemanusiaan, bermartabat, beradab itulah adat Minangkabau (Materi Pembinaan Pemangku Adat se-Sumatera Barat di Padang tanggal 4-7 Oktober 2017).

\section{Pengertian Ekonomi Adat}

Sedangkan ekonomi adat artikulasi dalam bahasa Minang adalah niago yang berasal kata ni-ago, artinya karakter atau simbol tawaran harga atau nilai jual beli. Dalam sejarah Tambo Alam Minangkabau telah menjelaskan bahwa ekonomi adat ini telah ada sejak peradaban awal Minangkabau berdiri, yaitu sejak Datuk Prapatie Nan Sabatang membentuk lareh bodi caniago berasal dari kata lareh artinya sistem adat, kemudian bodi artinya membawa serta, dan $\boldsymbol{c a}$ niago artinya tanpa memperjual belikan.

Maka dalam sistem adat Datuk Prapatie Nan Sabatang menegaskan bahwa adatnya tidak menentukan nilai status sosial seseorang, yang menjadi adat adalah "duduak samo randah, tagak samo tenggi". Dari pepatah diatas dapat diketahui bahwa sistem Adat Minangkabau telah melakukan salah satu dari prinsip ekonomi yakni persamaaan hak yang berkeadilan atau saling menguntungkan (Irwansyah, 2018).

Istilah ekonomi adat ini diperkenalkan oleh Tengku Irwansyah Angku Datuk Katumangguangan (Sumber Primer) dimaksudkan untuk membedakan mana yang ekonomi adat yang komunal atau mana ekonomi Islam dalam hukum ekonomi Islam. Sedangkan ekonomi adat ini sebenarnya adalah perilaku masyarakat adat Minangkabau yang komunal dalam melaksanakan prinsip-prinsip ekonomi secara tradisi turun temurun sejak dahulu kala, dengan mengedepankan kesetaraan, kesepakatan dalam sistem tawar menawar harga dengan barang dagangan atau sesuatu yang diperjual belikan secara adat dalam berbagai bentuk, namun pada prakteknya sesuai perkembangan zaman dan kondisi politik maka sistem ekonomi adat juga mengalami pergeseran nilai dan nyaris kehilangan jati diri, sehingga depersonalisasi (ketidakterlekatan) antara ekonomi adat dengan ekonomi Islam maka terjadilah pelemahan dan kekurangan sumber daya manusia dalam mengelola perekonomian secara keseluruhan.

\section{Mekanisme Ekonomi Adat}

Beberapa mekanisme ekonomi adat minang kabau dapat dilihat pada uraian dibawah ini:

1. Seorang penjual atau memberikan jasa kepada pembeli atau mendapatkan jasa, selalu melakukan transaksi dengan melakukan penawaran atau tawar menawar harga sampai mencapai kesepakatan harga. Penawaran dilakukan harga baik secara lisan atau gerak tubuh, baik secara terang terangan maupun 
tersembunyi didalam kain sarung atau kain penutup lainnya. Perilaku tradisi tawar menawar ini sudah ada sejakzaman hindu/budha sehingga ekonomi adat tidak mengenal transaksi harga yang telah ditentukan tanpa melalui mekanisme tawar menawar harga barang dan jasa sesuai kepatutan, sehingga menjadi tradisi seorang pembeli harus menawar harga walaupun tidak jadi membeli, itulah Mekanisme Ekonomi Adat yang mutlak dilakukan.

2. Sesorang pedagang atau pembeli selalu mengutamakan sistem jual beli berlangganan, walaupun ada tawaran lebih menggiurkan dari pihak lainnya, namun langganan masih tetap diutamakan, kecuali si langganan tidak berkenan atau tidak ada kabar berita sampai batas waktu transaksi yang dibutuhkan maka tawaran jual beli bisa di alihkan kepada pihak lain. Dengan pituah "Jan Taboli Lado Pagi"

3. Seorang pedagang atau pemberi jasa selalu menunjukkan barang atau jasa yang akan di perjual belikan kepada pembeli dengan menjelaskan kelebihan dan kekurangan daripada barang atau jasa yang ditawarkan sehingga menjadi pituah adat "Indak mamboli kuciang dalam kaghuang" arti tidak membeli kucing dalam karung ini adalah tidak membeli atau menjual barang atau jasa yang tidak jelas.

4. Seorang pedagang atau pemberi jasa selalu bersikap jujur dan transparan dalam berbisnis atau usahanya dengan menjelaskan harga pokok atau modal dasar barang dan jasa yang ditawarkan, sehingga pedagang dalam menawarkan harga setinggi apapun menjadi kelihaian si pembeli dalam menawar harga, sehingga mencapai kesepakatan "Lamak di awak, katuju di urang"

5. Seorang pedagang dan pembeli selalu mengedepankan istilah "Manenggang" artinya dalam tawar menawar harga selalu mengutamakan kepatutan harga tawar, sehingga menghindari kesalah pahaman dalam bertransaksi jual beli dan tidak terjadi penipuan serta pemalsuan dalam kesepakatan jual beli.

6. Setiap pemodal pelaku usaha dengan penjual jasa selalu mengutamakan prinsip ekonomi saling menguntungkan dengan pituah "Maukua samo panjang, Manimbang Samo Borek" artinya kedua belah pihak lebih mengutamakan azas musyawarah mufakat dalam melaksanakan bisnis bersama. Kemudian seluruh prinsip ilmu Ekonomi Adat yang dilaksanakan secara bersama sama, dengan melalui mekanisme kebersamaan hak dan kewajiban serta melalui modal dan usaha bersama. Sistem Ekonomi Adat ini kemudian di perkenalkan menjadi Usaha Bersama atau dikenal sebagai usaha Koperasi kepada masyarakat umum oleh orang Minang yang bernama Muhammad Hatta seorang Proklamator dan Wakil Presiden RI Pertama. Kemudian Indonesia menyebut Bung Hatta sebagai Bapak Koperasi Indonesia, padahal Koperasi adalah Ekonomi Adat warisan tradisi budaya Minangkabau sejak dulu kala, bukan ciptaan baru dari Bung Hatta.

7. Seorang pelaku ekonomi adat pada prinsipnya mengutamakan transparansi dan kejujuran serta ketabahan dalam berusaha yang selalu mengalami pasang surut, dengan istilah "Manggaleh" atau galeh bahasa Minang yang 
dimaksud adalah gelas kaca yang transparan bisa di lihat dengan pancaindra dan terukur, artinya mekanisme dalam berdagang atau manggaleh lebih mengutamakan kejujuran dan saling menguntungkan dengan harga yang pantas dan terukur, sehingga tidak menghalalkan segala cara dalam mendapatkan keuntungan. Serta ketabahan dalam bertransaksi agar menjadikan pribadi yang berbudi luhur dan berbudi bahasa yang santun, sesuai pituah adat "Muluik Manih Kucindan Murah, Budi Baiek Baso Tapakai"

8. Pada dasarnya tujuan ekonomi adat tradisi Minangkabau yang komunal, sesungguhnya untuk kesejahteraan bersama, kekayaan bersama demi kajayaan bersama sesuai menurut Granovetter, dalam (Damsar, 2002) merupakan tindakan ekonomi yang disituasikan secara sosial dan melekat (embedded) dalam jaringan sosial yang berlansung diantara mereka. Ekonomi adat Minangkabau telah menjadikan pola jaringan dalam kebersamaan, senasib sepenanggungan antar sesama urang Minang dimanapun berada dalam mencapai kesejahteraan bersama.

\section{Ekonomi Islam}

Menurut beberapa ahli pengertian ekonomi Islam adalah sebagai berikut:

1. M. Akram Kan adalah Ilmu ekonomi Islam bertujuan untuk melakukan kajian tentang kebahagiaan hidup manusia yang dicapai dengan mengorganisasikan sumber daya alam atas dasar berkerjasama dan pertisipasi.

2. Muhammad Abdul Mannan Ekonomi Islam adalah ilmu pengetahuan sosial yang mempelajari masalah-masalah ekonomi masyarakat yang di ilhami oleh nilai-nilai Islam.

3. M.Umer Chapra Ekonomi islam adalah sebuah pengetahuan yang membantu upaya realisasi kebahagiaan manusia melalui alokasi dan distribusi sumber daya yang terbatas, berada dalam koridor yang mengacu pada pengajaran Islam tanpa memberikan kebebasan individu atau tanpa perilaku makro ekonomi yang berkesinambungan dan tanpa ketidak seimbangan lingkungan (Mustafa, 2006: 16).

4. Muhammad Nejatullah Ash-Sidiqy Ilmu ekonomi Islam adalah respon pemikir muslim terhadap tantangan ekonomi pada masa tertentu. Dalam usaha keras ini mereka dibantu oleh Al-Qur'an dan Sunnah, akal (ijtihad) dan pengalaman.

5. Kursyid Ahmad Ilmu ekonomi Islam adalah sebah sistematis untuk memahami masalahmasalah ekonomi dan tingkah laku manusia secara relasional dalam perspektif Islam.

6. Menurut Adiwarman Karim, Ekonomi Islam diibaratkan satu bangunan yang terdiri atas landasan, tiang dan atap. (Karim A, Adiwarman, 2001).

Sadar akan hal itu, Adiwarman menawarkan pengertian ekonomi Islam sebagai ekonomi yang dibangun di atas nilai-nilai universal Islam. Nilainilai yang ia maksud adalah tauhid (keesaan), 'adl (keadilan), khilafah (pemerintahan), nubuwwah (kenabian) dan ma'ad (return). Secara singkat korelasi prinsip-prinsip tersebut dapat dijelaskan sebagai berikut. Tauhid, bermakna ke-Maha Tunggal-an Allah sebagai pencipta, pemilik semua 
yang ada di bumi dan di langit, pemberi rezeki yang Maha Adil yang berkuasa atas segalanya. Pengingkaran atas nilai tauhid dapat membawa manusia menjadi megalomania, merasa dirinya hebat, semua bisa diatur dengan uang.

Maka konsep keesaan Tuhan memberikan arah bagi pelaku ekonomi bahwa segala sesuatu adalah milik Allah, manusia hanyalah pemegang amanah. Karena itu ada sistem pertanggung jawaban bagi setiap tindakan ekonomi. Pada akhirnya, dalam skala makro prinsip pertanggung jawaban tersebut mendorong terwujudnya keadilan ( $a d l$ ) ekonomi dalam suatu masyarakat.

Akan tetapi, untuk dapat merealisasikan keadilan tersebut diperlukan adanya intervensi khilafah (pemerintah) sebagai regulator. Contoh terbaik terlaksananya sistem regulasi yang dijalankan pemerintah dalam masalah ekonomi ini dapat merujuk pada struktur sosial ekonomi pada masa Nabi (nubuwwah), terutama era Madinah. Prinsip nubuwwah di sini mengandung arti bahwa konsep ekonomi Islam adalah konsep untuk manusia, bukan untuk malaikat, serta mampu dijalankan oleh manusia, bukan oleh malaikat.

Nubuwwah adalah jawaban akan kebutuhan ini sebagaimana yang di contohkan Rasulullah tentang bagaimana melakukan kegiatan ekonomi yang membawa kesuksesan dunia akhirat. Tujuan akhir dari semua aktifitas ekonomi yang tersusun secara rapi melalui sistem tersebut tidak lain adalah maksimisasi hasil (ma'ad,return) yang tidak hanya menggunakan ukuran materil, tetapi juga aspek agama. Karena untuk menciptakan ekonomi yang kuat, tentu harus ada motivasi yang kuat bagi para pelakunya. Itu sebabnya, ekonomi Islam adalah ekonomi yang mencari laba. Namun 40|| Yunimar, Zakaria, Annesy dalam ekonomi Islam, untung tidak semata untung di dunia tetapi juga untung di akhirat. (Karim A, Adiwarman, 2001).

Setelah membicarakan tentang landasan ekonomi Islam, maka kini masalah tiangnya yang meliputi: Multiple Ownership, freedom to act, serta social justice. Islam mengakui adanya kepemilikan pribadi, kepemilikan bersama (syirkah), dan kepemilikan Negara. Hal ini sangat berbeda dengan konsep kapitalis klasik yang hanya mengakui kepemilikan pribadi dan konsep sosialis yang hanya mengakui kepemilikan bersama oleh negara. Multiple ownership (kepemilikan multijenis) merupakan derivasi dari prinsip tauhid, dimana manusia sebagai pemegang amanah di muka bumi diberi hak dan tanggung jawab yang sama dalam mengelola sumber daya yang tersedia.

Tetapi kebebasan manusia untuk mengeksploitasi sumber daya dibatasi oleh suatu tujuan bersama, yaitu terciptanya keadilan sosial (social justice) dan kesejahteraan (return, ma'ad) yang merata. Sementara proposisi kebebasan berusaha (freedom to act) memberikan motivasi kepada pelaku ekonomi dalam berusaha, baik dalam kapasitasnya sebagai individu maupun pemerintah sebagai pemegang regulasi, sebagaimana dipraktekkan pada masa Nabi.

Selain prinsip-prinsip di atas, terciptanya sistem ekonomi Islam juga memerlukan suatu tatanan norma atau hukum yang menjadi payung (atap) dan jaminan bagi keberlangsungannya. Dalam istilah Adiwarman, sistem norma atau hukum ini disebut sebagai akhlak ekonomi Islam. 
Ekonomi Islam sangat berbeda dengan ekonomi kapitalis, sosialis, maupun komunis. Ekonomi Islam bukan pula berada ditengahtengah ketiga sistem ekonomi tersebut. Sangat bertolak belakang dengan kapitalis karena lebih bersifat individual, sosialis memberikan semua tanggungjawab kepada warganya serta komunis yang ekstrim, ekonomi Islam menetapkan bentuk perdagangan serta pengkidmatan yang boleh dan tidak boleh di transaksikan.

Pendekatan masyarakat Islam terhadap kehidupan ditentukan oleh "pandangan dunia" yang terdapat pada Al-Qur'an sehingga secara umum ekonomi masyarakat islam jauh lebih rendah dari pada tujuan kehidupan secara keseluruhan. Menurut Al-Quran semua aktivitas yang patut dilakukan oleh manusia adalah mendapatkan falah untuk mencapai kebahagiaan hidup di dunia maupun di akherat salah satunya adalah ekonomi syariah (Najetullah Siddiqi, Muhammad. 2006).

Secara keseluruhan tujuan dari ekonomi syariah adalah 1) memenuhi kebutuhan hidup seseorang secara sederhana, 2) memenuhi kebutuhan keluarga, 3) memenuhi kebutuhan jangka panjang, dan 4) memberikan bantuan dan seimbang sesuai jalan Allah. Sehingga dapat diperjelas bahwa ekonomi syariah menjaga keseimbangan sektor riil dan moneter. Begitu pula pertumbuhan akan ada keterlambatan pemberian kebebasan terhadap teorinya (Karim A, Adiwarman, 2006).

Didalam ajaran Islam mengenal baik dalam ibadahnya kepada Tuhan dapat dibagi menjadi tiga, yaitu Syariah, Ibadah, dan Muamallah.
Ekonomi Islam termasuk dalam bidang syariah (Azis, Abdul, dkk. 2009). Ekonomi Islam harus mampu memberikan kesejahteraan seluruh masyarakat, memberikan rasa adil, kebersamaan dan kekeluargaan, serta mampu memberikan kesempatan seluas-luasnya kepada pelaku usaha yang menekankan pada empat sifat, yaitu kesatuan, keseimbangan, kebebasan, dan tanggung jawab.

Sedangkan tujuan dari ekonomi Islam adalah memberikan keselarasan bagi kehidupan di dunia. Nilai-nilai Islam bukan semata-mata untuk kehidupan muslim saja tetapi seluruh makhluk hidup di bumi. Esensi proses ekonomi Islam adalah pemenuhan kebutuhan manusia yang berlandaskan nilai-nilai Islam guna mencapai tujuan agama. Ekonomi Islam menjadi rahmat seluruh alam, yang tidak terbatas oleh ekonomi, sosial, budaya, dan politik dari bangsa. Ekonomi Islam mampu menangkap nilai fenomena masyarakat sehingga dalam perjalanannya tanpa meninggalkan sumber hukum teori Islam, bisa berubah.

\section{Mekanisme Akad Perdagangan Dalam Ekonomi} Islam.

\section{Pengertian dan Dasar Hukum Jual Beli}

Perdagangan atau jual-beli dalam bahasa arab sering al-mubadalah. Sebagaimana firman Allah SWT :

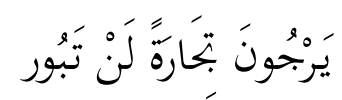

Mereka mengharapkan tijarah (perdagangan) yang tidak akan rugi (QS. Fathir : 29) 
Jual-beli menurut ulama Hanafiyah adalah tukar menukar sesuatu yang diingini dengan yang sepadan melalui cara tertentu yang bermanfaat, sedangkan menurut ulama Malikiyah, Syafi'iyah, dan Hanabilah jual beli adalah saling tukar menukar harta dengan harta dalam bentuk perpindahan milik dan kepemilikan (Haroen, 2000: 111). Dapat disimpulkan pengertian jual beli adalah "menukar barang dengan barang atau menukar barang dengan uang, yaitu dengan jalan melepaskan hak kepemilikan dari yang satu kepada yang lain atas dasar saling merelakan".

Jual-beli adalah aktifitas ekonomi yang hukumnya boleh berdasarkan kitabullah dan sunnah rasul-Nya serta ijma' dari seluruh umat Islam. Firman Allah SWT :

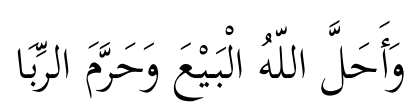

Dan Allah telah menghalalkan jual-beli dan telah mengharamkan riba. (QS. Al-Baqarah : ivo)

Sedangkan dari sunnah nabawiyah, Rasulullah SAW bersabda :

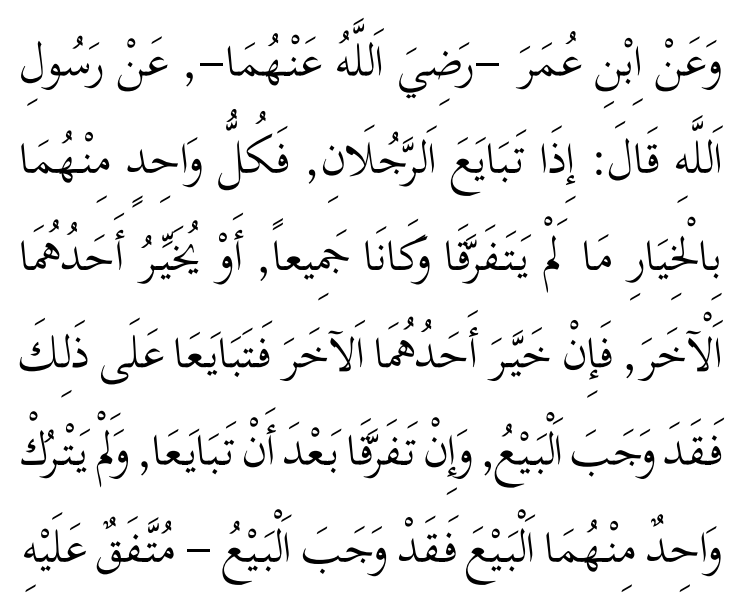

Dari Ibnu Umar r.a. bahwa Rasulullh saw bersabda: "Apabila dua orang melakukan jual-beli, maka masing-masing orang mempunyai hak khiyar (memilih antara membatalkan atau meneruskan jual-beli) selama mereka belum berpisah dan masih bersama; atau selama salah seorang di antara keduanya tidak menemukan khiyar kepada yang lainnya. Jika salah seorang menentukan khiyar pada yang lain, lalu mereka berjual-beli atas dasar itu, maka jadilah jual-beli itu". (HR. Muttafaq alaih)

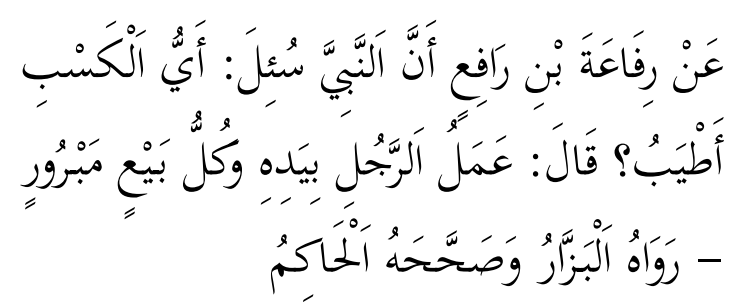

Dari Rifa'ah Ibnu Rafi' r.a. bahwa Rasulullah saw. pernah ditanya: Pekerjaan apakah yang paling baik?. Beliau bersabda: "Pekerjaan seseorang dengan tangannya dan setiap jual-beliyang bersih". (HR Al-Bazzar.(Hadits shohih menurut Hakim)

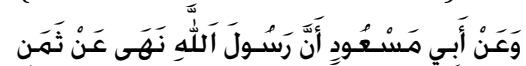

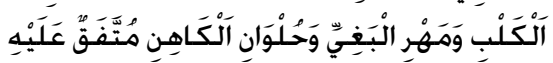

Dari Abu Mas'ud al-Anshary r.a. bahwa Rasulullah saw. melarang mengambil uang penjualan anjing, uang pelacuran dan upah pertenungan. (HR. Muttafaq Alaih)

\section{Bentuk-Bentuk Jual Beli}

Mazhab Hanafi membagi jual beli dari segi sah atau tidaknya menjadi tiga bentuk, yaitu:1. Jual beli yang shahih, Apabila jual beli itu disyariatkan, memenuhi atau syarat yang ditentukan, barang itu bukan milik orang lain, dan tidak terkait dengan khiyar lagi, maka jual beli itu shahih dan mengikat kedua belah pihak. Umpamanya, seseorang membeli suatu barang. Seluruh rukun dan syarat jual beli telah terpenuhi. Barang itu juga telah diperksa oleh pembeli dan tidak ada cacat, dan tidak ada yang rusak. Uang sudah diserahkan dan barangpun sudah diterima 
dan tidak ada lagi khiyar. 2. Jual beli yang bathil. Apabila pada jual beli itu salah satu atau seluruh rukunya tidak terpenuhi, atau jual beli itu pada dasarnya dan sifatnya tidak disyariatkan, maka jual beli itu bathil. Umpamanya, jual beli yang dilakukan oleh anak- anak, orang gila, atau barang-barang yang dijual itu barang-barang yang diharamkan syara' (bangkai, darah, babi dan khamar). (Haroen, 2000: 121)

\section{PENUTUP}

Berdasarkan hasil kajian di atas dapat disimpulkan bahwa tidak terdapat perbedaan yang mendasar antara ekonomi Adat Minangkau dengan Ekonomi Islam.

1. Ekonomi Adat Minangkabau tidak dapat dipisahkan dari ekonomi Islam, karena Falsafah Adat Minangkabau " Adat Basandi Syara', Syara' Basandi Kitabullah". Prinsip ekonomi bagi masyarakat Minang adalah perilaku secara adat yang tidak bertentangan dengan prinsip ekonomi Islam.

2. Persamaan antara ekonomi Adat Minang dengan Ekonomi Islam adalah melakukan penawaran harga atas dasar suka sama suka yang tidak bertentangan dengan prinsip ekonomi Islam.

3. Transparan dimana objek yang di perjual belikan jelas "Indak mambali kuciang dalam karuang". Prinsip ini sesuai dengan nilainilai ekonomi Islam, Dimana barang yang di perjualbelikan nyata dan jelas.

4. Prisnsip berlangganan dalam ekonomi Adat Minang merupakan wujud dari kepuasan terhadap pembeli maupun penjual. Prinsip ini selaras dengan nilai-nilai ekonomi dalam Islam.

5. Prinsip Kejujuran "lamak dek awak katuju dek urang" prinsip ini bermakna dalam ekonomi adat minang kabau. Prinsip ini sesuai dengan nilai-nilai ekonomi Isalam.

6. Kepatutan Harga "manenggang" kepatutan harga dalam ekonomi Adat Minang bertujuan memberikan kepuasan kepada pembeli dan penjual yang sesuai dengan nilai-nilai ekonomi Islam.

7. Prinsip saling menguntungkan "ma ukua samo panjang, manimbang samo barek" merupakan nilai-nilai ekonomi Adat Minang yang selaras dengan eknonomi Islam.

\section{DAFTAR KEPUSTAKAAN}

Damsar. (2002). Pengantar Sosiologi Ekonomi, Jakarta; PT. Raja Grafindo Persada.

Portal, 2016, Islam Belum Membumi dalam Perilaku Orang Minang, Padang: Singgalang Padang

Irwansyah. (2017). Materi Pembinaan Pemangku Adat Se-Sumatera Barat, Padang.

Adiwarman Karim. (2001). Ekonomi Islam Suatu Kajian Kontemporer, Jakarta: Gema Insani Press,.

Adiwarman Karim. (2006). Bank Islam-Analisis Fiqih dan Keuangan. Jakarta: PT. Raja Grafindo Persada

Ahmad izzan. (2006). Referensi Ekonomi Islam, Bandung: PT. Remaja Rosdakarya 
